\title{
Differentiation of human embryonic stem cells into hepatocytes in 2D and 3D culture systems in vitro
}

\author{
HOSSEIN BAHARVAND*, SEYED M. HASHEMI, SAEID KAZEMI ASHTIANI" and ALI FARROKHI \\ Department of Stem Cells, Royan Institute, Tehran, Iran
}

\begin{abstract}
Human embryonic stem cells (hESCs) have enormous potential as a source of cells for cell replacement therapies and as a model for early human development. In this study we examined the differentiating potential of hESCs into hepatocytes in two- and three-dimensional (2D and 3D) culture systems. Embryoid bodies (EBs) were inserted into a collagen scaffold 3D culture system or cultured on collagen-coated dishes and stimulated with exogenous growth factors to induce hepatic histogenesis. Immunofluorescence analysis revealed the expression of albumin (ALB) and cytokeratin-18 (CK-18). The differentiated cells in 2D and 3D culture system displayed several characteristics of hepatocytes, including expression of transthyretin, $\alpha-1$ antitrypsin, cytokeratin 8, 18, 19, tryptophan-2,3-dioxygenase, tyrosine aminotransferase, glucose-6-phosphatase (G6P), cytochrome P450 subunits $7 \mathrm{a} 1$ and secretion of alpha-fetoprotein (AFP) and ALB and production of urea. In 3D culture, ALB and G6P were detected earlier and higher levels of urea and AFP were produced, when compared with 2D culture. Electron microscopy of differentiated hESCs showed hepatocyte-like ultrastructure, including glycogon granules, welldeveloped Golgi apparatuses, rough and smooth endoplasmic reticuli and intercellular canaliculi. The differentiation of hESCs into hepatocyte-like cells within 3D collagen scaffolds containing exogenous growth factors, gives rise to cells displaying morphological features, gene expression patterns and metabolic activities characteristic of hepatocytes and may provide a source of differentiated cells for treatment of liver diseases.
\end{abstract}

KEY WORDS: human embryonic stem cell, hepatocyte, endoderm, differentiation, three-dimensional culture

\section{Introduction}

Currently, there is much interest in the generation of mature hepatocyte from stem cells. Hepatocyte transplantation has been shown to be a plausible treatment for human metabolic liver diseases (Fox et al., 1998). However, primary cultures of hepatocytes either do not replicate sufficiently in vitro to produce the number of cells necessary for transplantation or do not maintain their differentiated properties in vitro (Jones et al., 2002). Human embryonic stem cells (hESCs) have an enormous potential as a source of cells for cell-replacement therapies and as a model for early human development. These cells proliferate extensively in vitro in an undifferentiated state and maintain a normal karyotype. They also have the potential to differentiate into a variety of cell lineages (i.e., ectodermal, mesodermal and endodermal) (for review see Hoffman and Carpenter, 2005). Directed differentiation of hESCs is a useful tool to analyze the mechanisms controlling development of mammalian organs. It has recently been shown that endodermal differentiation toward the hepatic cell lineage may occur following spontaneous differentiation of hESCs (Itskovitz-Eldor et al., 2000; Schuldiner et al., 2000). Mouse ESCs have also been shown to differentiate into mature hepatocytes by growth factors (Hamazaki et al., 2001; Jones et al., 2002). In addition, mouse ESC-derived hepatocytes have been transplanted into animal models of liver injury, resulting in improved liver function (Kumashiro et al., 2005; Teramoto et al., 2005; Yamamoto et al., 2003). Research investigating hepatic differentiation from hESCs has been limited (Lavon et al., 2004; Rambhatla et al., 2003). Human ESCs could provide a source of hepatocytes

Abbreviations used in this paper: AFP, alpha fetoprotein; ALB, albumin; EB, embryoid body; CK, cytokeratin; G6P, glucose 6 phosphate; hESC, human embryonic stem cell; ICG, indocyanine green.

\footnotetext{
*Address correspondence to: Dr. Hossein Baharvand. Department of Stem Cells, Royan Institute, P.O. Box: 19395-4644, Tehran, Iran. Fax: +98-21-2240-9314. e-mail: Baharvand50@yahoo.com
} 

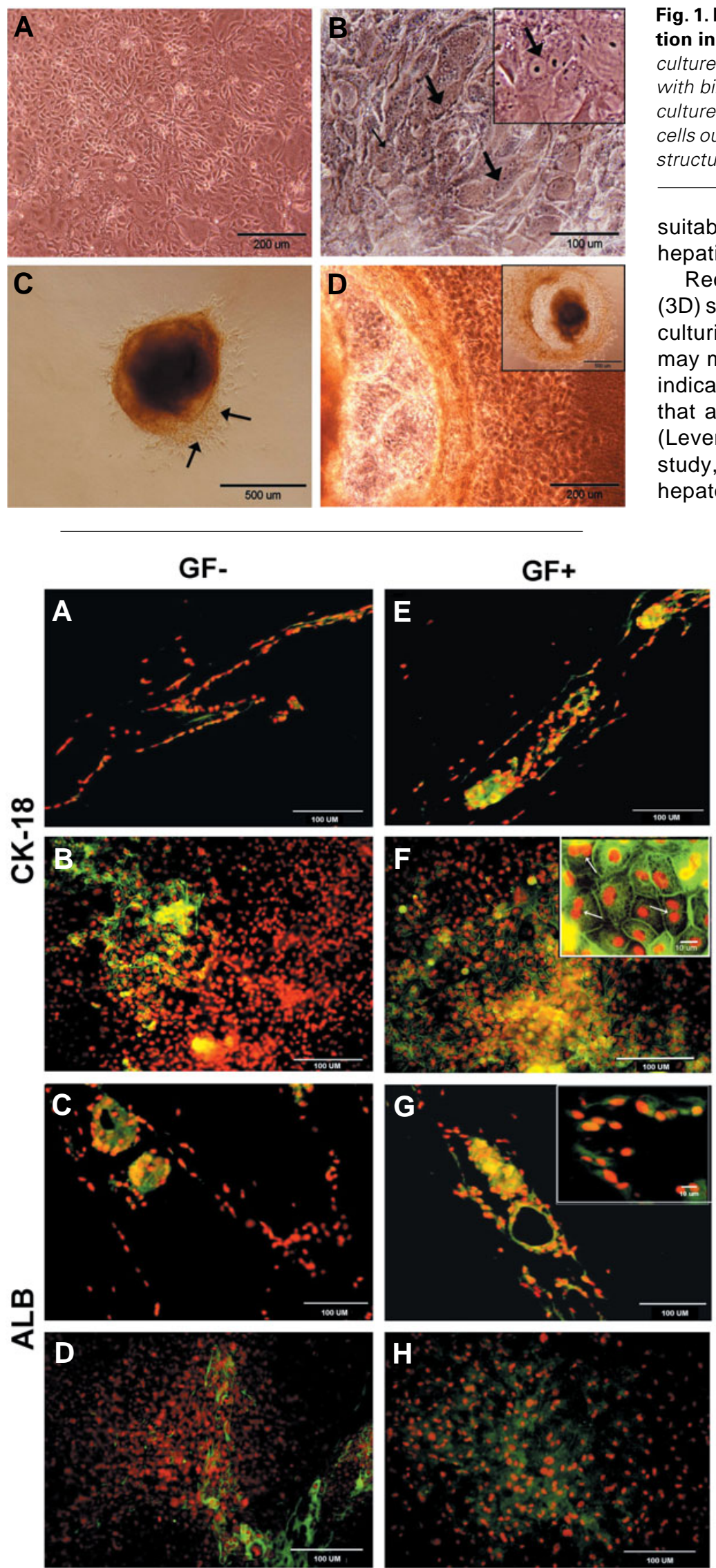

Fig. 1. Phase contrast microscopy of embryoid body (EB) differentiation in 2D and 3D culture systems. EB outgrowth on collagen-coated culture dishes proliferated as a 2D monolayer at day 5 (A) and day 24 (B) with binuclei and polygonal cells. EB implanted in collagen scaffold (3D culture system) at days 5 (C) and 24 (D). Arrows in (C) show migrating cells out of aggregate. The migrating cells formed cordlike and multilayer structures that were not present in 2D cultures (D).

suitable for cell transplantation and a useful model to study hepatic differentiation in vitro.

Recent tissue engineering studies using three-dimensional (3D) scaffold systems have demonstrated their effectiveness in culturing ESCs in vitro. Three dimensional culture conditions may mimic the in vivo environment more closely, with reports indicating distinct cellular behavior within 3D culture systems that are not observed in standard monolayer cultures or 2D (Levenberg et al., 2003; Levenberg et al., 2005). In the present study, we analyzed the potential of hESCs to differentiate into hepatocytes within $2 \mathrm{D}$ and $3 \mathrm{D}$ collagen culture systems and characterized cells by evaluating the expression of endodermal- and hepatocyte-specific markers, ultrastructure and function.

\section{Results}

Morphology of hESC-derived hepatocyte-like cells

Embryoid bodies formed by the suspension culture were implanted into the 3D space of collagen scaffolds or collagen-coated dishes (2D) system and then stimulated with exogenous growth factors. Cell morphology was assayed in 2D and 3D culture systems by phase contrast microscopy at early (Fig. 1 A,C) and late (Fig. 1 B,D) stages of differentiation. The 2D EBs proliferated under the in vitro conditions and by day 20 displayed morphological characteristics of hepatocyte-like cells, binuclei and polyhedral contours (Fig. 1B). Cells in the 3D culture system migrated out of aggregates and formed cordlike and multilayer structures and which were not observed in the 2D cultures (Fig. 1D).

\section{Immunocytochemical and immunohisto-chemichal staining}

To confirm in vitrohepatic differentiation from EBs, we analyzed expression of ALB (the most abundant protein synthesized by functional hepatocytes) and CK-18 (a cytokeratin indicative of hepatocyte morphology). The differentiated hESCs stained positively for both CK-18 (Fig. $2 \mathrm{~A}-\mathrm{F}$ ) and ALB (Fig. $2 \mathrm{C}-\mathrm{H}$ ) in 2D and 3D culture

Fig. 2. Representative immunofluorescent staining for albumin (ALB) and cytokinin (CK)-18. Human ESCs differentiated in the absence (A-D) or in the presence (E-H) of exogenous growth factors in 2D (A, E, C and G) and 3D culture systems (B, F, D and $H$ ) at day 20. Undifferentiated hESCs were negative for $A L B$ and CK-18 (data not shown). The CK-18-positive cells present in culture containing exogenous growth factors had polyhedral contours and two nuclei (arrows). Using the exogenous growth factors, the $A L B$ and $C K$-18-positive cells were further increased in both 2D and $3 D$ culture systems. Abbreviations: GF-, without exogenous growth factors; GF+, with exogenous growth factors. 
systems at day 22. The positive cells had large nuclei and polyhedral contours. Some of the positive cells were binuclear (Fig. 2F). The percentages of ALB and CK-18-positive cells were $15 \pm 7 \%$ and $14 \pm 5 \%$ in $2 \mathrm{D}$ and $18 \pm 10 \%$ and $16 \pm 6 \%$ in $3 \mathrm{D}$ spontaneously differentiated hESCs, respectively. Using the exogenous growth factors, the ALB and CK-18-positive cells could be further increased into $48 \pm 10 \%$ and $52 \pm 8 \%$ in $2 \mathrm{D}$ and $46 \pm 13$ $\%$ and $50 \pm 6 \%$ in $3 D$ culture systems, respectively $(P<0.01)$.

\section{Endoderm and hepatic specific gene expression}

The mRNA expression of endodermal and hepatocyte-specific genes, such as hepatocyte nuclear factor $3 \beta$ (HNF3 $\beta$ ), $\alpha$-fetoprotein (AFP), albumin (ALB), transthyretin (TTR), $\alpha$-1-antitrypsin (AAT), cytokeratins (CK-8, CK-18 and CK-19), tryptophan-2,3dioxygenase (TDO), tyrosine aminotransferase (TAT) glucose-6phosphatase (G6P) and cytochrome P450 subunits 7a1 (Cyp7a1) was observed during hESCs differentiation (Fig. 3A). In this study, the undifferentiated hESCs did not express mRNA of the endodermal or hepatocyte lineage genes, although, the hESCs expressed OCT4, a pluripotent marker, CK-19, which is expressed in biliary epithelial cells and hepatoblasts and HNF3 $\beta$, which is a liver-enriched transcription factor (Ishizaka et al., 2002). We found that OCT-4 was down-regulated during differentiation and endodermal and hepatocyte-specific genes were upregulated upon differentiation. Figure 3, shows the expression of TTR, AAT, AFP, TDO, CK-18 and Cyp7a1 at day 8 of differentiation in both $2 D$ and $3 D$ cultures. In the 3D culture system, mRNA expression of ALB and G6P was detected earlier than that detected in 2D culture. Some of these markers are also expressed in visceral endoderm, which is known to be present in differentiating hESCs cultures. Thus we analyzed the expression of the hepatic-specific marker,Cyp7a1 (Asahina et al., 2004). Additionally we compared liver-specific gene expression profiles between differentiated hESCs with and without exogenous growth factors in 2D and 3D cultures and found that the differentiating hESCs without exogenous growth factors expressed endodermal-specific genes such as HNF3 $\beta$, AFP, TTR, AAT, CK-8, CK-18, CK-19, TDO, ALB and Cyp7a1, but not,G6P and TAT at day 24 (Fig. 3B).

\section{Alpha-fetoprotein, albumin and urea production}

Alpha-fetoprotein was not secreted by hESCs, whereas continuously increased during differentiation in $3 \mathrm{D}$ and $2 \mathrm{D}$ culture systems, with a noted increase observed at days $24(P<0.01)$ and $28(\mathrm{P}<0.05)$ in presence of exogenous growth factors compared with spontaneously differentiated hESCs. In addition, AFP production with exogenous growth factors in $3 \mathrm{D}$ culture system is significantly higher than $2 \mathrm{D}$ culture system at day $28(\mathrm{P}<0.05)$. No significant difference in AFP secretion was detected between different treatments prior to day 20 (Fig. 4A). Undifferentiated hESCs did not secrete ALB, whereas after induction of hepatic differentiation, ALB secretion continuously increased in 3D and 2D culture systems and reached maximal values at day 24 . However, there was not significant difference in all groups. In addition, detection of urea production was performed to confirm whether differentiated hESCs within 2D and 3D culture systems could support and maintain hepatic metabolic functions. Urea production was significantly increased in 3D culture compared with $2 \mathrm{D}$ culture at days $18(\mathrm{P}<0.01), 22(\mathrm{P}<0.001)$ and $28(\mathrm{P}<$ $0.01)$. Urea production in spontaneous differentiated cells was also significantly lower than cultures with additional growth factors (Fig. 4C, day 18: $P<0.01$, days 22 and 28: $P<0.001$ ). Urea production by undifferentiated hESCs was not detected (data not shown).

\section{Glycogen synthesis}

Glycogen storage was determined by PAS staining in hepaticlike cells cultured within 3D culture system at day 20 (Fig. 5B). Spontaneously differentiated cells were negative for PAS staining (Fig. 5A). Positively stained glycogen granules were detected in the cytoplasm of cells (Fig. 5C).

\section{Indocyanine green cellular uptake}

Indocyanine green (ICG) is an organic anion that is clinically used as a test substance to evaluate liver function since it is nontoxic and eliminated exclusively by hepatocytes (Yamada et al., 2002). In the present study, we examined cellular uptake of ICG to identify differentiated hepatocyte-like cells. On day 20 of EB culture, ICG-positive cells were detected in abundance in 2D and 3D culture systems (Fig 5 E,F). Cellular uptake of ICG in spontaneous differentiated cells was low (Fig. 5D) and undifferentiated hESCs were negative for ICG (data not shown).

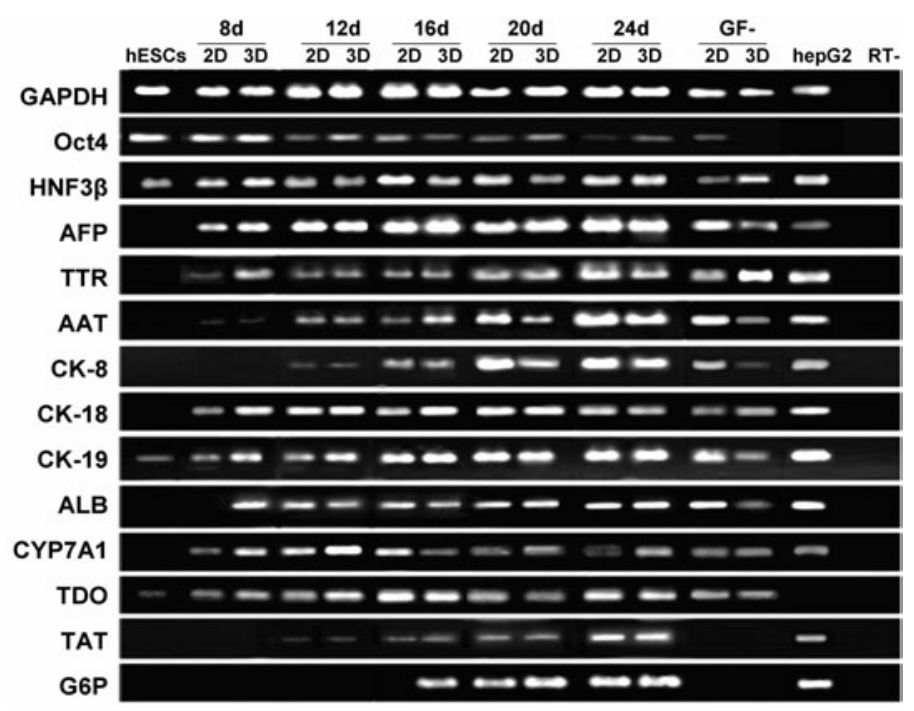

Fig. 3. RT-PCR analysis of liver-specific gene expression by hESCderived cells in 3D and 2D culture systems in the presence of exogenous growth factors and in spontaneous differentiated hESCs. The expression of hepatocyte nuclear factor $3 \beta$ (HNF3 $\beta$ ), $\alpha$-fetoprotein (AFP), albumin (ALB), transthyretin (TTR), $\alpha$-1-antitrypsin (AAT), cytokeratins (CK-8, CK-18 and CK-19), tryptophan-2,3-dioxygenase (TDO), tyrosine aminotransferase (TAT), glucose-6-phosphatase (G6P), cytochrome P450 subunit 7a1 (Cyp7a1), OCT4 and GAPDH (internal control) during in vitro differentiation are shown at days $0,8,12,16,20$ and 24 . In the $3 D$ culture system, mRNA expression of ALB and G6P were detected earlier than in the $2 D$ culture system. The G6P and TAT genes were not expressed in spontaneous differentiated cultures. The human hepatoma cell line (hepG2) was used as positive control. Tests were repeated in triplicate and for each assay was performed independently two times. GF-, hESCs differentiated for 24 days without exogenous growth factors; $R T$, reverse transcription in the absence of $C D N A ; 3 D$, three-dimensional system; 2D, two-dimensional system. 


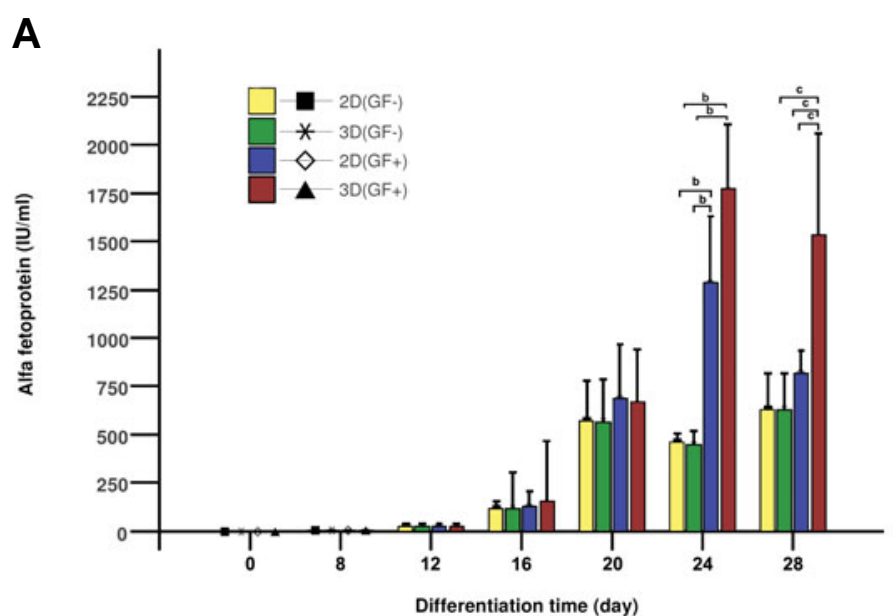

B

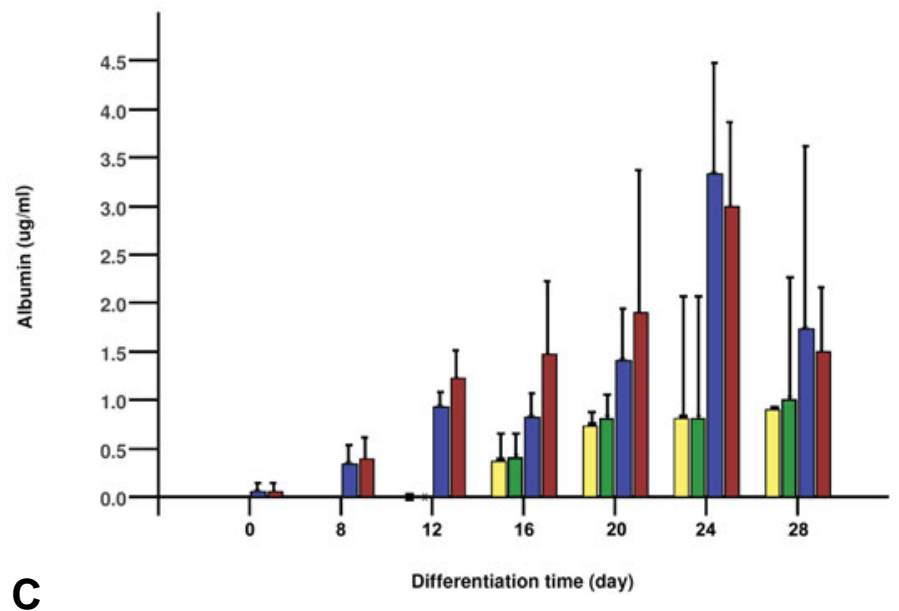

C

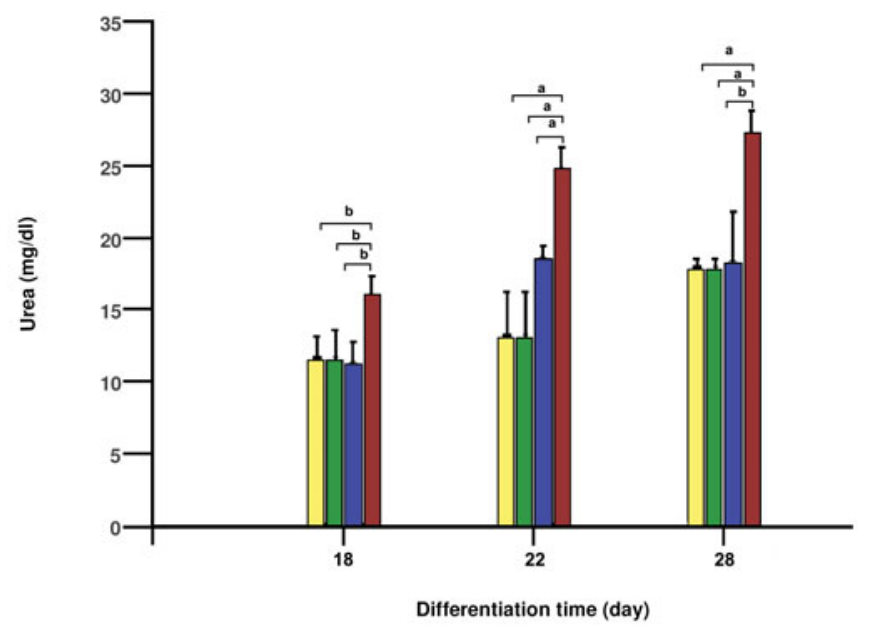

Fig. 4. Alpha-fetoprotein (AFP), albumin (ALB) and urea production by hESC-derived cells in $3 D$ and 2D culture systems at varying developmental stages. (A) AFP, (B) ALB and (C) urea production. All products were increased during differentiation in the presence of growth factors and AFP and urea were produced at significantly higher levels in $3 D$ culture compared with $2 D$ culture. Tests were repeated in triplicate and repeated three times for each assay. GF-, without exogenous growth factors; GF+, with exogenous growth factors; $a, P<0.001 ; b, P<0.01 ; c$, $P<0.05$.

\section{Ultrastructural characteristics of hepatocyte-like cells}

In collagen scaffold cultures, semi-thin sections stained with toluidine blue showing hepatocyte-like cells in direct contact with adjacent cells (Fig. 5). Ultrastructural studies of differentiated cells revealed that cell ultrastructure was similar to hepatocytes (Ishii et al., 2005; Yamada et al., 2002). Numerous mitochondria, lysosomes, prominent nucleoli, well-developed Golgi apparatuses and rough and smooth endoplasmic reticuli (rES and sER) were observed in the cytoplasm of these cells (Fig. 5 B-E). The nuclei were occasionally irregular in shape and typically displayed a high nuclear to cytoplasmic ratio. Interdigitation of cytoplasmic extensions was observed between adjacent cells (Fig. 5E). Bile canaliculi were also occasionally observed between adjacent cells. Glycogon granules were also detected in the cytoplasm of the cells (Fig. 5 C,E).

\section{Discussion}

In this study, we investigated the endodermal and hepatic differentiation of hESCs within a $3 \mathrm{D}$ collagen scaffold-culture system and in a 2D monolayer culture system, on collagencoated dishes supplemented with exogenous growth factors. The mRNA expression of endodermal and hepatocyte-specific genes was detected at varying stages of hESC differentiation. Differentiated cells were found to produce urea, secrete ALB and AFP, store glycogens and ICG uptake, indicative of differentiation of hESCs into functional hepatocyte-like cells. Furthermore, differentiated hESCs showed distinctive ultrastructural features characteristic of hepatocytes. Recently, it was reported that mouse ESCs can generate cells displaying hepatocyte characteristics upon spontaneous differentiation (Hamazaki et al., 2001; Jones et al., 2002). Human ESCs can also spontaneously differentiate into endoderm in vitroand thus may be an additional useful model to use for producing endodermal and hepatic cell types (Jones et al., 2002). Most recently, Lavon et al. (2004) analyzed the capacity of hESCs to differentiate into hepatocytes by using suspension culture of EBs for 20 days and then dissociated and plated these EBs for an additional 10 days with aFGF. In another study, Rambhatla et al. (2003) induced hepatic differentiation by treatment with sodium butyrate. In the present study, we used 5day-old EBs and induced differentiation using a method as described by Hamazaki et al. (2001) in 2D and 3D collagen matrix. Teratani et al. (2005), examined matrix-dependent hepatic cell growth which indicated that mouse ESC-derived hepatocytes are sensitive to extracellular matrix component types and that type I collagen may be optimal for directing mouse ESCs toward the hepatocyte lineage. Another study evaluated the effect of 3D culture on hepatocyte differentiation in mouse ESCs, although did not determine the functional properties of differentiated mouse ESCs (Imamura et al., 2004).

The hepatic endoderm develops next to the cardiac mesoderm and is affected by secreted factors from the mesodermal cells during normal development (Zaret, 2001; Zaret, 2002). The growth factors, aFGF and bFGF are secreted from the cardiac mesoderm at the time of hepatic induction. The response to this factor is restricted to the endoderm tissue, which uniquely expresses the receptors for these factors (Jung et al., 1999). When visceral endoderm and hepatic differentiation were examined by gene expression during in vitro mouse ESC differentiation, an 
early marker, TTR, was detected within 3 days following growth factors treatment. The markers, AFP and AAT were detected at days 6 to 9. Alpha-fetoprotein is a marker of endodermal differentiation and an early fetal hepatic marker (Hamazaki et al., 2001; $\mathrm{Hu}$ et al., 2004). TTR, AAT and AFP represent endodermal differentiation and hepatocytes. Albumin mRNA expression was first detected at day 12 (Hamazaki and Terada, 2003). In addition, CK-8 and CK-18 which are involved in maintaining the skeleton structure of hepatocytes and epithelial cells are expressed in the cytoplasm of differentiating fetal liver in vivo (Hu et al., 2004; Hamazaki and Terada, 2003). G6P and TAT are predominantly expressed in the liver during late gestation and are considered the markers of hepatic mature differentiation (Hamazaki et al., 2001). In this study, differentiating hESCs without exogenous growth factors expressed the endodermal specific genes AFP, TTR, AAT, CK-8, CK-18, CK-19 and ALB, but not G6P and TAT at later stages of differentiation. Our findings indicate that AFP, ALB and urea production by $\mathrm{hESC}$-derived cells during differentiation was significantly lower during spontaneous differentiation, compared with culture containing exogenous growth factors, which indicates that hESCs can spontaneously differentiate into visceral endodermal cells or early hepatic lineage cells. However, their ability to differentiate into functional hepatocyte-like cells is poor. In addition, the expression of CK-19 (Tan et al., 2002) did not alter during differentiation, suggesting the presence of hepatic progenitors or incomplete differentiation into biliary epithelial cells. The expression of liver-specific serum protein genes such as ALB, AFP and TTR, as well as the endoderm-specific transcription factor gene, HNF3 $\beta$, can be found in the yolk sac, a derivative of the extra embryonic endoderm, as well as in the fetal liver. Thus, these markers are insufficient to prove in vitro differentiation into hepatocytes, though they can be used to show early endoderm commitment in EBs derived from ESCs (Yamada et al., 2002; Asahina et al., 2004). In addition, Cyp7a1 was identified as a liverspecific gene that was not expressed in the yolk sac (Asahina et al., 2004). In the present study, we found that the expression of the liver-specific gene Cyp7a1 is induced in culture with exogenous growth factors. These results demonstrate that hESCs can differentiate in vitrointo hepatocytes derived from definitive endoderm.

By electron microscopy hepatocyte-like cells in the collagen scaffolds had a immature organization of intracellular organelles and architecture including rER, sER, Golgi apparatus and intercellular canaliculi, glycogen particles and lysosomes. Tight junctions and gap junctions were formed around the bile canaliculi. Intercellular canaliculi developed well and some formed bile canaliculus-like structures (Ishii et al., 2005; Yamada et al., 2002).

To determine whether cells with morphological and phenotypic characteristics of hepatocyte-like cells also acquired functional properties, a number of functional assays were performed to investigate metabolic functions of hepatocytes such as urea production and AFP and ALB secretion. In comparison with $2 \mathrm{D}$ culture, earlier gene expression patterns of ALB and G6P and higher detection levels of urea and AFP in 3D culture systems suggest that $3 \mathrm{D}$ culture systems provide a microenvironment that is conducive to normal progenitor cell kinetics and enhanced cell differentiation. The advantages of using 3D tissue culture systems include the ability to mimic in vivo histoarchitecture, easy manipulation of cells or tissues and an optimal used to promote cell-to-cell and/or matrix interactions (Imamura et al., 2004).

In conclusion, our findings illustrate that hESC differentiation in 3D culture systems more closely resemble the in vivo environment in regards to inducing correct cell morphology, cellular environment, gene expression and biological behavior of the cells. Human ESCs may provide an alternative source of hepato-
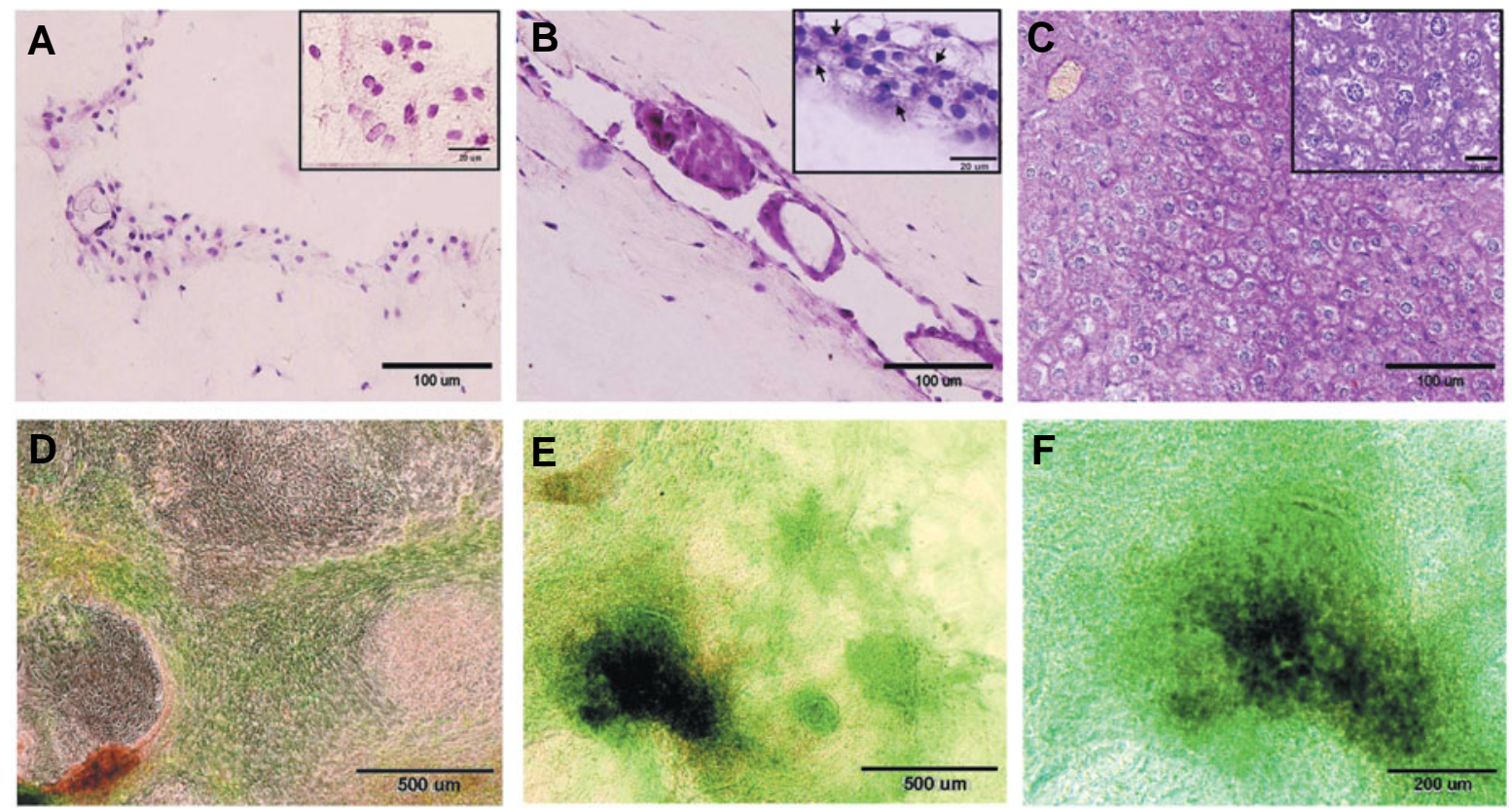

Fig. 5. Glycogen storage determined by periodic acid-Schiff (PAS) staining and cellular uptake of indocyanine green. (A) Spontaneously differentiated hESCs were PAS negative. (B) Differentiated hESCs in the presence of exogenous growth factors at day 20 displayed glycogen granules in 3D culture system. (C) Adult liver section as positive control. Cellular uptake of indocyanine green, an organic anion that is clinically used as a test substance to evaluate liver function in spontaneously differentiated cells. (D) Differentiated cells in 2D (E) and in 3D (F) culture systems in presence of growth factors. 

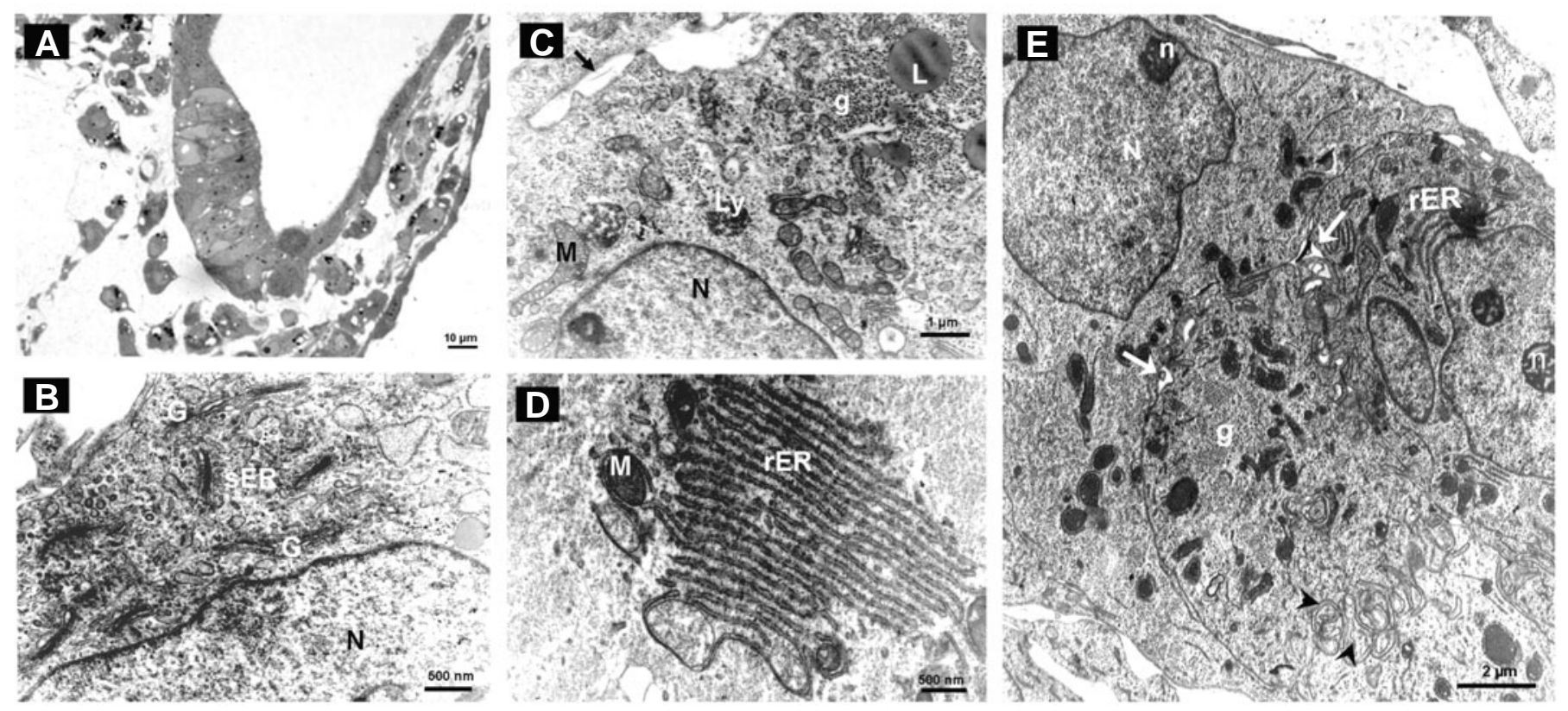

Fig. 6. Ultrastructural characteristics of hepatocyte-like cells in 3D culture at day 28. (A) Semi-thin sections stained with toluidine blue. (B-E) Micrograph of hepatocyte-like cells derived from hESCs indicate hepatocyte characteristics including mitochondria (M), rough endoplasmic reticulum (rER), smooth endoplasmic reticulum (sER), glycogen (g), nucleolus (n), lipid granule (L), lysosome (Ly), Golgi apparatus (G) and nucleus (N). The arrow and arrowhead indicate bile canaliculus and interdigitation of adjacent cells, respectively.

cytes for the development of a bioartificial liver system for use in patients waiting for a liver donor or provide a useful tool for pharmaceutical models. However, additional research is necessary in order to improve the efficiency of differentiation.

\section{Materials and Methods}

\section{Culture of human ESCs}

The hESC line, Royan H1 (Baharvand et al., 2004) was cultured on mitomycin-C (Sigma) treated mouse embryonic fibroblast (MEF) feeders, plated on gelatin (Sigma)-coated tissue culture dishes (Falcon). Human ESCs were maintained in hESC medium (80\% Knockout Dulbecco's modified Eagle's medium (KO-DMEM; Gibco/BRL) supplemented with 20 $\%$ ES-qualified fetal calf serum (ES-FCS Gibco/BRL), 2 mM glutamine (Gibco), $0.1 \mathrm{mM} \beta$-mercaptoethanol (Sigma), $1 \%$ nonessential amino acid stock (Gibco/BRL), $5 \mathrm{mg} / \mathrm{ml}$ insulin, $5 \mu \mathrm{g} / \mathrm{ml}$ transferrin, $5 \mu \mathrm{g} / \mathrm{ml}$ selenium (ITS, Gibco/BRL), $100 \mathrm{U} / \mathrm{ml}$ penicillin and $100 \mu \mathrm{g} / \mathrm{ml}$ streptomycin (Gibco/BRL). The cells were grown in $5 \% \mathrm{CO}_{2}$ and $95 \%$ humidity and then mechanically passaged on fresh mitomycin-treated MEFs approximately every seven days.

\section{Induction of hepatic differentiation in vitro}

To induce differentiation, the colonies of hESCs were mechanically dissociated (300-500 cells) and cultured as individual pieces in "hanging drops" $(20 \mu \mathrm{l})$ for 2 days in hESC medium to produce EBs. Formed EBs were transferred into suspension culture containing same medium in 100 $\mathrm{mm}$ petri dishes and cultured for an additional 3 days. The EBs were then cultured in 24-well tissue culture dishes containing a 3D scaffold, Vitrogen (type I collagen, Cohesion, Palo Alto, CA, USA) (2 mm height). Using a stereomicroscope, an incision of about $0.1 \mathrm{~mm}$ was made in each collagen scaffold and $5 \mathrm{EBs}$ were implanted into the incision. As controls, EBs were also cultured on collagen-coated dishes as a 2D culture system. Several growth factors were added into the culture medium at varying days following differentiation including, acidic fibroblast growth factors (aFGF, R\&D Systems) $(100 \mathrm{ng} / \mathrm{ml})$ added on day 9 until day 12 to induce hepatic differentiation. Hepatocyte growth factor (HGF, R\&D Systems)
$(20 \mathrm{ng} / \mathrm{ml})$ was then added from day 12 until day 20 , as a mid-stage factor Oncostatin M (OSM, R\&D Systems) $(10 \mathrm{ng} / \mathrm{ml})$, dexamethasone (Dex, Sigma) $\left(10^{-7} \mathrm{M}\right), 5 \mathrm{mg} / \mathrm{ml}$ insulin, $5 \mathrm{mg} / \mathrm{ml}$ transferrin and $5 \mu \mathrm{g} / \mathrm{ml}$ selenium (ITS, Gibco/BRL) were added as late stage factors from day 15 until day 20. Cells were cultured until day 28. As a control treatment, in vitro spontaneous differentiation was induced in hESCs by culture within the $2 \mathrm{D}$ and/or 3D systems in the absence of growth factors for 28 days.

\section{Immunohistochemical and immunocytochemical staining}

Formalin-fixed paraffin-embedded collagen gels were cut into $4-\mu \mathrm{m}$ thick sections and mounted on glass slides coated with poly-L-lysine. The sections were deparafinized in xylene and rehydrated in 100, 96 and 70 $\%$ ethanol for $5 \mathrm{~min}$ and rinsed in phosphate-buffered saline (PBS). The sections were incubated in blocking buffer $(0.1 \mathrm{M}$ PBS containing $0.5 \%$ normal goat serum, $0.2 \%$ Triton $\mathrm{X}-100)$ for $1 \mathrm{~h}$ and thereafter in primary antibodies for $12 \mathrm{~h}$ at $4{ }^{\circ} \mathrm{C}$ diluted in blocking buffer. The antibodies used in this study were mouse monoclonal anti-albumin (ALB, 1:200 R\&D Systems) and mouse monoclonal anti-cytokeratin 18 (CK-18, 1:200 Chemicon). Adjacent sections served as negative controls and were processed using identical procedures, except for incubation without the primary antibody. The secondary antibody used was IgG FITC-conjugated goat anti-mouse (1:100, Sigma). Incubation with the secondary antibody was performed at $25^{\circ} \mathrm{C}$ for $30 \mathrm{~min}$. to prepare $2 \mathrm{D}$ cultured cells for immunostaining, cells were rinsed in PBS and fixed using $4 \%$ paraformaldehyde (Sigma). Cells were cultured in PBS containing $1 \%$ goat serum to inhibit unspecific labeling (30 min at room temperature) and labeled with primary and secondary antibodies as described above. Cells were counterstained with $5 \mathrm{mg} / \mathrm{ml}$ propidium iodide and analyzed using the fluorescence microscope (Olympus, BX51, Japan). The percentages of immunopositive cells relative to total number of propidium iodidelabelled cells were recorded.

\section{RNA extraction and RT-PCR analysis}

Total RNA was extracted from cultured cells using the NucleoSpin ${ }^{\circledR}$ RNA II kit (Macherey-Nagel, Düren, Germany). Prior to reverse transcription (RT), RNA samples were digested with DNase I (EN0521; Fermentas) to remove contaminating genomic DNA. Extracted RNA 
was treated by DNase I (EN0521; Fermentas) to avoid cross contamination of RNA by genomic DNA. Standard RT was performed using 2 $\mu \mathrm{g}$ total RNA, oligo (dT)18 and the RevertAid ${ }^{\mathrm{TM}} \mathrm{H}$ Minus First Strand cDNA Synthesis Kit (K1622; Fermentas) according to the manufacturer's instructions. The cDNA samples were subjected to polymerase chain reaction (PCR) amplification using human specific primers designed using different exons (Table 1). Amplification conditions were as follows: Initial denaturation at $94^{\circ} \mathrm{C}$ for 5 min followed by 30 cycles of denaturation at $94^{\circ} \mathrm{C}$ for $30 \mathrm{sec}$, annealing at $59-70^{\circ} \mathrm{C}$ for $45 \mathrm{sec}$ (see table refer to temperatures used), extension for $45 \mathrm{sec}$ at $72^{\circ} \mathrm{C}$ and a final polymerization at $72^{\circ} \mathrm{C}$ for $10 \mathrm{~min}$. The PCRs were performed in triplicate. The PCR products were analyzed by gel electrophoresis on $1.5 \%$ agarose and stained with ethidium bromide $(10 \mu \mathrm{g} / \mathrm{ml})$ and visualized and photographed on a UV transluminator (Uvidoc, UK). As a positive control, human hepatoma cell line, HepG2, (Pasteur Institute, Tehran, Iran) was used.

\section{Alpha-fetoprotein and albumin production}

Conditioned media from the differentiated hESCs cultured both with and without exogenous growth factors in 2D and 3D cultures (5 EBs in every well of 24-wells dishes) were collected at days $0,8,12,16,20$, 24 and 28 and frozen at $-20^{\circ} \mathrm{C}$ until assay. The conditioned media were assayed for AFP production using a chemiluminescence Immunoassay kit (Diasorin-Liaison) and for ALB production using a quantitative enzyme-linked immunoassay kit (Albumin ELISA, Orgentech Diagnostica, Germany) according to manufacturer's recommendations. The conditioned media of undifferentiated hESCs (day 0 ) was used as a negative control.

\section{Urea production}

The hESCs (5 EBs per well in 24-well dish) were incubated with $1 \mathrm{~mL}$ medium containing $5 \mathrm{mM} \mathrm{NH}_{4} \mathrm{Cl}$ (Sigma) for $24 \mathrm{~h}$ in $5 \% \mathrm{CO} 2$ at $37^{\circ} \mathrm{C}$ on days 18,22 and 28 . Following this incubation, supernatant was collected and Urea concentrations were measured by using a colorimetric assay kit (Pars azmun, Iran). Undifferentiated hESCs (day 0) were used as a negative control.

\section{Periodic acid-Schiff staining for glycogen}

Glycogen storage was evaluated using paraffin-embedded tissues. Briefly, sections were oxidized in 1\% periodic acid (Sigma) for 5 min and rinsed three times in deionized water. Slides were then treated with Periodic Acid Schiff's (PAS) reagent (Sigma) for $15 \mathrm{~min}$, rinsed in deionized water for 5-10 min, stained with Mayer's hematoxylin (Sigma) for $1 \mathrm{~min}$ and finally rinsed in deionized water.

\section{Indocyanine green cellular uptake}

To determine cellular uptake of indocyanine green (ICG), $1 \mathrm{mg} / \mathrm{ml}$ of indocyanine green (Sigma) in DMEM containing $10 \%$ FBS was added to cell cultures at late stage of differentiation and incubated at $37^{\circ} \mathrm{C}$ for 15 min. Cells were then rinsed three times with PBS and cellular uptake of ICG was examined. Cell dishes were then replated with fresh DMEM containing 10\% FBS. The ICG was undetected in cells 6 hours post staining (Yamada et al., 2002).

\section{Transmission electron microscopy (TEM)}

The samples at day 24 were processed for TEM as previously described (Baharvand et al., 2005). Briefly, the samples were fixed using

TABLE 1

PRIMERS AND THE REACTION CONDITIONS FOR RT-PCR OF DIFFERENTIATING HEPATOCYTES FROM hESCs

\begin{tabular}{|c|c|c|c|c|}
\hline Genes & Primer Sequence ( $5^{\prime}$-> $\left.3^{\prime}\right)$ & $\begin{array}{c}\text { Annealing } \\
\text { temperature }\left({ }^{\circ} \mathrm{C}\right)\end{array}$ & $\begin{array}{l}\text { Length } \\
\text { (bp) }\end{array}$ & Gene bank code \\
\hline GAPDH & $\begin{array}{l}\text { CCA GGT GGT CTC CTC TGA CTT CAA CAG } \\
\text { AGG GTC TCT CTC TTC CTC TTG TGC TCT }\end{array}$ & 62 & 224 & NM_002046 \\
\hline OCT4 & $\begin{array}{l}\text { CTT GCT GCA GAA GTG GGT GGA GGA A } \\
\text { CTG CAG TGT GGG TTT CGG GCA }\end{array}$ & 65 & 187 & NM002701 \\
\hline $\begin{array}{l}\text { Hepatocyte nuclear factor } 3 \beta \\
\text { (HNF3 } \beta \text { ) }\end{array}$ & $\begin{array}{l}\text { CCA CCA CCA ACC CCA CAA AAT G } \\
\text { TGC AAC ACC GTC TCC CCA AAG T }\end{array}$ & 60 & 294 & NM_021784 \\
\hline Apha-fetoprotein (AFP) & $\begin{array}{l}\text { GCA GCC AAA GTG AAG AGG GAA GA } \\
\text { GTC ATA GCG AGC AGC CCA AAG AAG }\end{array}$ & 69 & 216 & NM_001134 \\
\hline Transthyretin (TTR) & $\begin{array}{l}\text { GGT GAA TCC AAG TGT CCT CTG AT } \\
\text { GTG ACG ACA GCC GTG GTG GAA }\end{array}$ & 61 & 352 & NM_000371 \\
\hline Alpha-1-antitrypsin (AAT) & $\begin{array}{l}\text { CCA TGT TTG TCA AAG AGC AAC T } \\
\text { GGA AGT AAG GTA TAG TCA GGT GAT }\end{array}$ & 61 & 345 & NM_001085 \\
\hline Cytokeratin-8 (CK-8) & $\begin{array}{l}\text { CAG ATC AAG TAT GAG GAG CTG CA } \\
\text { AGC TGG TGC GGC TGA AGG AT }\end{array}$ & 63 & 503 & NM_002273 \\
\hline Cytokeratin-18 (CK-18) & $\begin{array}{l}\text { CCA TGC GCC AGT CTG TGG AG } \\
\text { GTG GTG CTC TCC TCA ATC TGC T }\end{array}$ & 65 & 322 & NM_000224 \\
\hline Cytokeratin-19 (CK19) & $\begin{array}{l}\text { TGA GGT CAT GGC CGA GCA GAA C } \\
\text { CAT GAG CCG CTG GTA CTC CTG A }\end{array}$ & 69 & 331 & NM_002276 \\
\hline Albumin (ALB) & $\begin{array}{l}\text { CTGCTTGAATGTGCTGATGACAG } \\
\text { GGCATAGCATTCATGAGGATCTG }\end{array}$ & 60 & 365 & NM_000477 \\
\hline $\begin{array}{l}\text { Cytochrome P450 subunits } \\
\text { 7a1 (Cyp7a1) }\end{array}$ & $\begin{array}{l}\text { GAG AAG GCA AAC GGG TGA AC } \\
\text { ATC GGG TCA ATG CTT CTG TG }\end{array}$ & 63 & 277 & NM_000780 \\
\hline $\begin{array}{l}\text { Tryptophan-2,3-dioxygenase } \\
\text { (TDO) }\end{array}$ & $\begin{array}{l}\text { GGT TTA GAG CCA CAT GGA TT } \\
\text { ACA GTT GAT CGC AGG TAG TG }\end{array}$ & 62 & 425 & NM_005651 \\
\hline $\begin{array}{l}\text { Tyrosine aminotransferase } \\
\text { (TAT) }\end{array}$ & $\begin{array}{l}\text { GCT AAG GAC GTC ATT CTG ACA AG } \\
\text { GTC TCC ATA GAT CTC ATC AGC TAA G }\end{array}$ & 67 & 354 & NM_000353 \\
\hline Glucose-6-phosphatase (G6P) & $\begin{array}{l}\text { GCT GAA TGT CTG TCT GTC ACG AA } \\
\text { GCA GAA GGA CAA GAC GTA GAA GA }\end{array}$ & 60 & 494 & NM_000151 \\
\hline
\end{tabular}


$2.5 \%$ glutaraldehyde in $0.1 \mathrm{M} \mathrm{PBS}(\mathrm{pH} 7.4)$ for $2 \mathrm{~h}$. After washing with PBS, samples were post-fixed with $1 \%$ osmium tetra oxide for $1.5 \mathrm{~h}$, again washed in PBS, dehydrated in an acetone series and then embedded in epoxy resin. After resin polymerization, sections of approximately $50 \mathrm{~nm}$ were cut and double stained with uranyl acetate and lead citrate. Electron micrographs were taken using a Zeiss EM 900 transmission electron microscope (Zeiss, Germany).

\section{Statistical analysis}

All experiments were performed in triplicate. The results were given as means \pm standard deviation (SD). Statistical analysis was performed by using a Student's $t$ test with significance reported when $\mathrm{P}<0.05$. For quantitative evaluation of ALB and CK-18 positive cells, at least $700 \mathrm{PI}$ positive cells were analyzed.

\section{Acknowledgments}

We gratefully thank Dr. Vanessa Hall for helpful comments on the manuscript. We also acknowledge the assistance of Dr. Abdoulhossein Shahverdiand Dr. Ahmad Vosugh in supporting this research, Mansoureh Shahsavani, Adeleh Taei, Mohammad Pakzad and Abbas Piriaei for technical assistance. This project was supported partly by the industrial development and renovation organization of Iran.

\section{References}

ASAHINA, K., FUJIMORI, H., SHIMIZU-SAITO, K., KUMASHIRO, Y., OKAMURA, K., TANAKA, Y., TERAMOTO, K., ARII, S. and TERAOKA, H. (2004). Expres sion of the liver-specific gene cyp7a1 reveals hepatic differentiation in embryoid bodies derived from mouse embryonic stem cells. Genes Cel/s 9: 1297-308.

BAHARVAND, H., ASHTIANI, S.K., VALOJERDI, M.R., SHAHVERDI, A., TAEE, A. and SABOUR, D. (2004). Establishment and in vitro differentiation of a new embryonic stem cell line from human blastocyst. Differentiation 72: 224-9.

BAHARVAND, H., AZARNIA, M., PARIVAR, K. and ASHTIANI, S.K. (2005). The effect of extracellular matrix on embryonic stem cell-derived cardiomyocytes. $J$ Mol Cell Cardio/38: 495-503.

FOX, I.J., CHOWDHURY, J.R., KAUFMAN, S.S., GOERTZEN, T.C., CHOWDHURY, N.R., WARKENTIN, P.I., DORKO, K., SAUTER, B.V. and STROM, S.C. (1998) Treatment of the crigler-najjar syndrome type i with hepatocyte transplantation. N Eng/ J Med 338: 1422-6.

HAMAZAKI, T., IIBOSHI, Y., OKA, M., PAPST, P.J., MEACHAM, A.M., ZON, L.I. and TERADA, N. (2001). Hepatic maturation in differentiating embryonic stem cells in vitro. FEBS Lett 497: 15-9.

HAMAZAKI, T. and TERADA, N. (2003). In vitro differentiation of embryonic stem cells into hepatocytes. Methods Enzymo/365: 277-87.

HOFFMAN, L.M. and CARPENTER, M.K. (2005). Characterization and culture of human embryonic stem cells. Nat Biotechno/23: 699-708.

HU, A.B., CAI, J.Y., ZHENG, Q.C., HE, X.Q., SHAN, Y., PAN, Y.L., ZENG, G.C., HONG, A., DAI, Y. and LI, L.S. (2004). High-ratio differentiation of embryonic stem cells into hepatocytes in vitro. Liver Int 24: 237-45.

IMAMURA, T., CUI, L., TENG, R., JOHKURA, K., OKOUCHI, Y., ASANUMA, K., OGIWARA, N. and SASAKI, K. (2004). Embryonic stem cell-derived embryoid bodies in three-dimensional culture system form hepatocyte-like cells in vitro and in vivo. Tissue Eng 10: 1716-24.

ISHII, T., YASUCHIKA, K., FUJII, H., HOPPO, T., BABA, S., NAITO, M. MACHIMOTO, T., KAMO, N., SUEMORI, H., NAKATSUJI, N. et al. (2005). In vitro differentiation and maturation of mouse embryonic stem cells into hepatocytes. Exp Cell Res 309: 68-77.

ISHIZAKA, S., SHIROI, A., KANDA, S., YOSHIKAWA, M., TSUJINOUE, H., KURIYAMA, S., HASUMA, T., NAKATANI, K. and TAKAHASHI, K. (2002).
Development of hepatocytes from es cells after transfection with the hnf-3beta gene. FASEB J16: 1444-6.

ITSKOVITZ-ELDOR, J., SCHULDINER, M., KARSENTI, D., EDEN, A., YANUKA O., AMIT, M., SOREQ, H. and BENVENISTY, N. (2000). Differentiation of human embryonic stem cells into embryoid bodies compromising the three embryonic germ layers. Mol Med 6: 88-95.

JONES, E.A., TOSH, D., WILSON, D.I., LINDSAY, S. and FORRESTER, L.M. (2002). Hepatic differentiation of murine embryonic stem cells. Exp Cell Res 272: 15-22.

JUNG, J., ZHENG, M., GOLDFARB, M. and ZARET, K.S. (1999). Initiation of mammalian liver development from endoderm by fibroblast growth factors. Science 284: 1998-2003.

KUMASHIRO, Y., ASAHINA, K., OZEKI, R., SHIMIZU-SAITO, K., TANAKA, Y., KIDA, Y., INOUE, K., KANEKO, M., SATO, T., TERAMOTO, K. et al. (2005). Enrichment of hepatocytes differentiated from mouse embryonic stem cells as a transplantable source. Transplantation 79: 550-7.

LAVON, N., YANUKA, O. and BENVENISTY, N. (2004). Differentiation and isolation of hepatic-like cells from human embryonic stem cells. Differentiation 72 : 230-8.

LEVENBERG, S., BURDICK, J.A., KRAEHENBUEHL, T. and LANGER, R. (2005). Neurotrophin-induced differentiation of human embryonic stem cells on threedimensional polymeric scaffolds. Tissue Eng 11: 506-12.

LEVENBERG, S., HUANG, N.F., LAVIK, E., ROGERS, A.B., ITSKOVITZ-ELDOR, J. and LANGER, R. (2003). Differentiation of human embryonic stem cells on three-dimensional polymer scaffolds. Proc Natl Acad Sci USA 100: 12741-6.

RAMBHATLA, L., CHIU, C.P., KUNDU, P., PENG, Y. and CARPENTER, M.K. (2003). Generation of hepatocyte-like cells from human embryonic stem cells. Cell Transplant 12: 1-11.

SCHULDINER, M., YANUKA, O., ITSKOVITZ-ELDOR, J., MELTON, D.A. and BENVENISTY, N. (2000). Effects of eight growth factors on the differentiation of cells derived from human embryonic stem cells. Proc Nat/ Acad Sci USA 97: 11307-12.

TAN, J., HYTIROGLOU, P., WIECZOREK, R., PARK, Y.N., THUNG, S.N., ARIAS, B. and THEISE, N.D. (2002). Immunohistochemical evidence for hepatic progenitor cells in liver diseases. Liver22: 365-73.

TERAMOTO, K., ASAHINA, K., KUMASHIRO, Y., KAKINUMA, S., CHINZEI, R., SHIMIZU-SAITO, K., TANAKA, Y., TERAOKA, H. and ARII, S. (2005). Hepatocyte differentiation from embryonic stem cells and umbilical cord blood cells. $J$ Hepatobiliary Pancreat Surg 12: 196-202.

TERATANI, T., YAMAMOTO, H., AOYAGI, K., SASAKI, H., ASARI, A., QUINN, G., SASAKI, H., TERADA, M. and OCHIYA, T. (2005). Direct hepatic fate specification from mouse embryonic stem cells. Hepatology 41: 836-46.

YAMADA, T., YOSHIKAWA, M., KANDA, S., KATO, Y., NAKAJIMA, Y., ISHIZAKA, S. and TSUNODA, Y. (2002). In vitro differentiation of embryonic stem cells into hepatocyte-like cells identified by cellular uptake of indocyanine green. Stem Cells 20: 146-54

YAMAMOTO, H., QUINN, G., ASARI, A., YAMANOKUCHI, H., TERATANI, T., TERADA, M. and OCHIYA, T. (2003). Differentiation of embryonic stem cells into hepatocytes: Biological functions and therapeutic application. Hepatology 37: 983-93.

ZARET, K.S. (2001). Hepatocyte differentiation: From the endoderm and beyond. Curr Opin Genet Dev 11: 568-74.

ZARET, K.S. (2002). Regulatory phases of early liver development: Paradigms of organogenesis. Nat Rev Genet 3: 499-512.

Received: July 2005 Reviewed by Referees: November 2005 Modified by Authors and Accepted for Publication: May 2006 Published Online: June 2006 